\title{
Effects of torrefaction on some physico-mechanical and organoleptic characteristics of maize flour blended peanut patties rolled into sticks in Benin
}

\author{
Emile Adjibadé SANYA*, Clément AHOUANNOU, Gédéon CHAFFA and \\ Roger AHOUANSOU
}

\author{
Laboratory of Applied Energetics and Mechanics (LEMA) of Polytechnic School of Abomey Calavi (EPAC), \\ University of Abomey - Calavi (UAC), 01 POB: 2009 Cotonou, Republic of Benin. \\ *Corresponding author; E-mail: easanyas@gmail.com ; Tel. (+229) 98271804.
}

\begin{abstract}
The cake, from peanut seeds oil-extraction, is classically used for cattle feed manufacture and fertilizers. It may also well be valorized as crispy patties for human food. Several variants of peanut patties, "kluiklui", rolled into sticks, are very prized in Benin. This passion for patties, coupled with fairly high price of groundnut seeds, incited patties producers to innovative and ingenious manipulations. From then, crude or roasted maize flour was incorporated to replenish many groundnut variants patties. This article is devoted to study influences of applied torrefaction to maize grains giving added flour during formulation of fried groundnut's defatted dough into different variants on some physical (residual humidity, apparent density, volume expansion rate), mechanical (fracture strength) and organoleptic (color, crustiness, taste) properties of the produced patties. The results showed that torrefaction causes significant decrease of residual water content, volume expansion rate and breaking strength, making corresponding patties less crusty and less well-liked by consumers as proven by realized tasting results. However, torrefaction of maize flour also induced increase of the patties apparent density. Nevertheless, the latter was less affected in comparison with the previous three cited characteristics. The groundnut patties variants, blended of maize flour at respective rates of 5\% and $10 \%$ (weight-in-mix), were the most affected by torrefaction process relatively to recorded feeble breaking strength values and thus, the best prized by patties consumers.
\end{abstract}

(C) 2015 International Formulae Group. All rights reserved.

Keywords: maize seeds, bulk density, expansion rate, breaking strength, crustiness, taste.

\section{INTRODUCTION}

Peanut or groundnut, Arachis hypogaea L., of Fabaceae or Papilionaceae family (Linné, 1753; Maïti and Wesche-Ebeling, 2002), is a tropical plant native from South America. Its seeds, cheap, are an important source of proteins, including "lectins" (30\%) having the binding property specifically to oligosaccharides, lipids (50\%) mainly those composed of mono-unsaturated fatty acids
(54\%) and a significant amount of saturated fatty acids (19.6\%) and polyunsaturated $(21.6 \%)$. The peanut carbohydrates content is around 7.5\% (Souci et al., 2008; Paulet 2010). It is not very interesting from a nutritional point of view, because of its high content of saturated fatty acids, unlike rapeseed oil, olive oil or sunflower, and its little omega-3. It also contains vitamins and minerals (FAO, 1993, 2006, 2010). It spreads throughout the world 
(Europe, Asia and Africa) and mainly in United States, where consumption remains particularly high, about $3.2 \mathrm{~kg} /$ year/person (FAO, 2010). The two biggest peanut producers are China and India, and the largest exporters Argentina, India and United States (Fao, 2006; ITC, 2009; Xiaoyan et al., 2012). From taxonomic point of view, peanut is different from nuts: walnuts, hazelnuts, pistachios, pine nuts, almonds, cashew nuts. Consumption patterns differ greatly from one country to another: United States retain $60 \%$ of their production for manufacture of food products and exports $20 \%$ while Argentina and South Africa export more than $75 \%$ of their production (FAO, 1993; Maiti and Wesche-Ebeling, 2002). The average peanut production in Benin is around 130,000 t/year since 2008 (INSAE, 2012) and more than half of crop is to scale processing into oil, condiments and various cakes. The remaining production is sold mainly in urban centers. The peanut patties, made in traditional way from the seed cakes, symbolize a popular food in West Africa in general and Benin in particular. Commonly known as "kluiklui" (Fon language) in Benin, peanut patties constitute a favorite food of certain social classes including craftsmen, laborers, pupils and students. Indeed, residues from peanut oil extraction (cakes) still retain a relatively significant nutritional value (FAO, 2010; Xiaoyan et al., 2012). They constitute the raw material in manufacture of traditional patties "kluiklui" (Adjadja, 2004; Guedou, 2011; Sanya et al., 2013). The problem is that, nowadays, for socio-economic reasons, most patties producers, chiefly the women, integrate maize flour into defatted groundnut dough, mainly during periods of groundnut seeds high prices. Such practice actually allows producer women a refloating of the finished product, in order to maintaining its known size and its selling price during the lean periods. Subsequently, patties taste and storage time are compromised (Guedou, 2010). Two kinds of maize flour were incorporated in patties dough formulation: the first's from crude maize grains and the second from torrefied seeds. Recent data from USADepartment of Agriculture and General Association for Maize Producers (USDAAGPM, 2013) indicate that maize global production is of 839 million tons in 2013 (against 860 million tons for a consumption of 866.7 Mt in 2011-2012). This makes maize the most cultivated cereal in the world $(41 \%)$ before the wheat (40\%). Maize is, among the Beninese food products, the most cultivated. Its production continues to progress slowly with $1,165,953 \mathrm{t}$ in $2011-2012$ and $1,174,563 \mathrm{t}$ in 2012-2013 against 867,154 $\mathrm{t}$ in 2008-2009 (INSAE, 2012). It's undeniably subject to larger number of food transformations: over 40 sub-products (Nago, 1989; Nago and Hounhouigan, 1990; Hounhouigan, 1994). Most maize processing technologies, in artisanal sector, derive from local cultural heritage (domestic techniques transmitted and perpetuated through family education) gradually integrated and larger scale used in trading activities. A better scientific knowledge, for mastering of the patties production process, is indispensable for boosting promotion of the groundnut sector added-value (maize also) through that of peanut patties in Benin. For purpose, series of research works were then initiated at Laboratory of Applied Energetics and Mechanics (LEMA) of Polytechnic School of Abomey-Calavi. This work was undertaken to analyze the influences of torrefaction of maize grains (giving the incorporated flour into the defatted dough of peanut seeds baked for producing the rolled into sticks patties "kluiklui"), on some of their physical, mechanical and sensory quality characteristics.

\section{MATERIALS AND METHODS}

The reported exploratory works were realized in three (03) different sites. The process steps, going from seeds roasting to peanut dough obtention, were performed in a patties production unit at Godomey-Togoudo city (Benin). This unit has served as site of the practicum stay for mastering of patties manufacturing process. Measurements of 
physicomechanical parameters and organoleptic tests on the collected samples were carried out at Laboratory of Applied Energetic and Mechanics (LEMA) and at Laboratory for Research in Applied Biology (LARBA) of Polytechnic School of University of Abomey-Calavi (EPAC-UAC).

\section{Raw materials for groundnut patties production}

The raw materials, used in the manufacture of studied patties, are mainly groundnut seeds and maize grains. Dry peanut seeds, about twenty eight (28) kg, not including quantity used for preliminary trials, and a little more than seven (7) $\mathrm{kg}$ of maize grains, all from the white variety, consumed locally, were acquired directly from the sellers who usually supply these speculations to an experienced patties production unit.

\section{Patties manufacture's equipment}

For patties production, the equipment includes, among others, aluminum pans, a small angled table, a kneading table, a large flat pan, a perforated ladle, a sieve, spoons, firewood, a kiln, a stool without forgetting maize mill services (and peanuts too). The patties "kluiklui" are peanut seeds based food. Its local manufacturing is still largely artisanal, complex and accomplished following the traced steps in the left branch of Figure 1 and briefly described in next paragraphs. Having brown color, pulling to caramelizing, the groundnut patty is very prized by Beninese people.

\section{Description of some methods key-steps Seeds torrefaction/roasting process}

After properly sorted the good seeds of dry groundnuts seeds, they are subjected to torrefaction process (step 3 on the left of Figure 1). The procedure consists in partially toasting the seeds by continuously stirring them in an aluminum pan under a moderate heat (at supplied temperature comprised between 170 and $190{ }^{\circ} \mathrm{C}$ ) for 20 to $30 \mathrm{~min}$. Thermo chemical mechanism of torrefaction/roasting is to weaken, by means of heat, the oil retention cellular links in other cellular components of seeds (proteins, cellulose, starch) to initiate the release of oil. Like that applied treatment to coffee, roasting is source of two chemical reactions: Maillard's reaction on the one hand, wherein sugar and water, heated together, melts and water vaporizes, giving place to sort of caramelizing matter and secondly, Strecker's reaction which occurs and changes the seeds pigmentation (Robert et al., 2002; Redgwell et al., 2002; Fallico et al., 2003; Matiacevich and Buera, 2006; Bruneton, 2009). The success of torrefaction process, for the case of the groundnut seeds, is that it causes a partial removal of their protective film (seed coat), seeing sometimes, its complete removal.

\section{Dehulling - winnowing roasted seeds}

After a relative cooling $\left(35-40{ }^{\circ} \mathrm{C}\right)$, the seeds are hand rubbed to loosen the seed coat (film), an operation in which the germs are often detached. This is followed by the winnowing in which hulls and germs are separated from the cotyledons. These cotyledons constitute the useful part of seeds researched for following steps of processing.

\section{Milling of cotyledons}

The cotyledons are ground using grains' mill and it results groundnut dough. The grind of cotyledons requires prior removal of residues or traces of residual flour from mill's wheels and cage, to avoid defilement of this peanut dough.

\section{Kneading - pressing and oil-extraction}

This obtained groundnut dough is allowed to cool at ambient air. It is then subjected to kneading added of few pints of tepid water, from time to time, first in an appropriate bowl and then on an inclined table on the bowl which allows collecting the dripping groundnut oil. This dough kneading continues until near of oil depletion, accessing by this way to defatted groundnut seeds' dough. It is known that appropriate groundnut dough's, for manufacture of good quality patties, are those containing about $26 \%$ by oil weight (Paulet, 2010; Sanya et al., 2013). 
Incorporation of ingredients and maize flour

It has become common, nowadays, to make seasoning of the defatted dough of groundnut seeds, using various ingredients.

One adds different spices to get the corresponding seasoned patties "kluiklui", chiefly with chili, garlic, ginger or other ingredients. It's also at this process step that maize flour, obtained from crude or torrefied seeds, is incorporated in seeds' defatted dough. The formulation of groundnut defatted dough, seasoned with classical ingredients using different maize flour percentages, made either of torrefied (roasted) or raw (non torrefied/unroasted) seeds, was performed according to constitutions shown in Table 1 .

\section{Frying the rolled pastry sticks}

After the shaping step, the seasoned dumplings, rolled in sticks (diameter $8.5-10$ $\mathrm{mm}$ ), are introduced into hot oil at $90-110^{\circ} \mathrm{C}$ in a fryer pan, using some of extracted peanut oil, dried of the contained water, for frying. The mechanism of frying involves cooking coupled to drying of molded dough. This causes the existent water migration inside the product at surface where it vaporizes in form of bursting bubbles. Approximately eight to ten minutes after, the patties are golden and cooked. They are therefore removed from the hot oil, collected using a perforated ladle and deposited in a strainer where they are cleaned of excess oil coupled to a beneficial loss of water vapor.

\section{Patties' trimming and sampling}

The patties' trimming is the done set operation steps, in Laboratory of Applied Energetics and Mechanics (LEMA), consisting of visually identifying, from the produced groundnut patties of a given variant, those likely identical, at diameter value point of view, proceeding by this way to the elimination of those distorted; thereafter, cut individually each patty stick and his like, in order to obtain twelve (12) cylindrical specimens apparent diameter $8-10 \mathrm{~mm}$ and 30 $\mathrm{mm}$ length (height) retained for all realized tests. This length was adopted in view to reaching several apparently homogeneous samples from each stick of patties. But, it also matched the minimal requirement for operating the used equipment in crustiness effort testing in Research Laboratory in Applied Biology (LARBA). This cumbersome operation is repeated six (06) times per variant of peanut patties made of flour from non torrefied maize grains, on one hand, and of torrefied maize grains, on the other, at contents of $5 \%, 10 \%, 15 \%$ and $20 \%$ (weight basis), at intervals of about two weeks, during this exploratory research campaign. For achieving patties sampling, we have also made use of various accessories like aluminum foil, cutter, metal saw blades, graduated plastic ruler, markers and adhesive paper.

\section{Determination of produced patties' characteristics \\ Analysis of patties residual water content}

The water content of patties samples was determined using the procedure of AFNOR NF-90.93 by gravimetric method. A ventilated oven, trademark MEMMERT D06060, Model L400 (France) having temperature range of $30-225{ }^{\circ} \mathrm{C}$, was used for convective drying of the patties samples. Three samples of milled groundnut patties into fine powders with the aid of a RETSCH Mill, at taken mass M of about $10 \mathrm{~g}$ each, are collected in known empty mass aluminum cups $\left(\mathrm{M}_{\mathrm{v}}\right)$. The entire cup + crushed mass $M_{1}$ is then inserted in a ventilated oven for heating-drying at $103 \pm 2$ ${ }^{\circ} \mathrm{C}$, for at least 8 hours during which mass catches are made at time intervals. Drying is stopped when attaining mass constancy for dried product $\mathrm{M}_{2}$, constancy marked through three consecutive weighings. During these tests, coming out of oven and before each weighing, samples are cooled for $10 \mathrm{~min}$ in a Nalgene ISO-9001 desiccator. The sample's water content (W), on a dry basis (db), expressed in percentage, is determined by applying the formula:

$\mathrm{W}=100 \cdot\left(\mathrm{M}_{1}-\mathrm{M}_{2}\right) /\left(\mathrm{M}_{2}-\mathrm{M}_{\mathrm{v}}\right)(\%)$

\section{Analysis of patties bulk density}

The bulk density of patty's sample (rolled into cylindrical shaped stick) is ratio between the mass (M) of patty sample, taken in the 
open air using the EHW-ED digital display laboratory balance $(3000 \mathrm{~g} / 0.1 \mathrm{~g}$ precision) and its apparent volume $\left(\mathrm{V}_{\mathrm{A}}\right)$. Patty sample's bulk density is calculated following the known classical formula:

$\rho_{\mathrm{A}}=\mathrm{M} / \mathrm{V}_{\mathrm{A}}$

To achieve this, one first determines dimensions of this likely cylindrical sample, namely:

- the apparent diameter $\left(\mathrm{D}_{\mathrm{A}}\right)$, calculated as the arithmetic average of three (03) measured diameters $D_{1}, D_{2}$ and $D_{3}$, using Facom caliper $150 \mathrm{~mm}-1 / 100^{\text {th }}$ type, where $\mathrm{D}_{1}$ is the diameter value at $5 \mathrm{~mm}$ of sample's first base, $\mathrm{D}_{2}$ diameter value at middle and $\mathrm{D}_{3}$, the diameter value at $5 \mathrm{~mm}$ from the second base of sample:

$\mathrm{D}_{\mathrm{A}}=\left(\mathrm{D}_{1}+\mathrm{D}_{2}+\mathrm{D}_{3}\right) / 3$

- the length or real height of cylindrical sample (H), kept constant equal to $30 \mathrm{~mm}$ in all of these carried out tests in current investigation;

- the sample's apparent volume $\left(\mathrm{V}_{\mathrm{A}}\right)$ is determined by the aid of standard formula:

$\mathrm{V}_{\mathrm{A}}=\left(\pi \cdot \mathrm{H} \cdot \mathrm{D}_{\mathrm{A}}^{2}\right) / 4$

Then, we deduce the apparent density $\left(\rho_{A}\right)$ expressed in $\mathrm{g} / \mathrm{cm}^{3}$ for each patty sample.

Assessment to patties' volume expansion rate

Before frying step, the obtained sticks after the rolling of groundnut paste pellets are carefully cut into $30 \mathrm{~mm}$-height samples. Diameters $\mathrm{D}_{1}, \mathrm{D}_{2}$ and $\mathrm{D}_{3}$ are taken as previously described before placing each sample in the hot oil for frying. After $8 \mathrm{~min}$ frying, the preceding three (03) diameters and sample height is measured again. These measures are repeated on twelve (12) samples from each of the elaborated patties variants incorporating respectively $0 \%, 5 \%, 10 \%, 15 \%$ and $20 \%$ (weight) flour made of roasted maize seeds, on the one hand and on those produced variants using $0 \%, 5 \%, 10 \%, 15 \%$ and $20 \%$ (weight) flour from unroasted maize seeds, on the other. The volume expansion rate $\left(\varepsilon_{\mathrm{v}}\right)$ is then calculated by dividing the volume difference $\left(\mathrm{V}_{\mathrm{A}}-\mathrm{V}_{0}\right)$ multiplied by 100 by initial volume $\left(\mathrm{V}_{0}\right)$ :

$\varepsilon_{\mathrm{V}}=100 \cdot\left(\mathrm{V}_{\mathrm{A}}-\mathrm{V}_{0}\right) / \mathrm{V}_{0}$

wherein $\left(\mathrm{V}_{\mathrm{A}}\right)$ is final volume of the obtained patty sample, by subjecting, the seasoned dough (incorporated with flour provided either by torrefied maize seeds or by non torrefied), rolled into sticks and cut in $30 \mathrm{~mm}$-height, to the frying process. It should be stressed the delicacy and caution required during dimensions measurement on the dough sticks sample, material which still remains relatively soft and easily deformable. This primarily constitutes a source of potential errors in these kinds of measures.

\section{Breaking strength assessment for crustiness effort analysis}

The taken samples, into the adopted 30 mm-height cut dimensions to their real diameter - from the manufactured nine (09) variants groundnut patties, are then inserted in a ventilated oven, set to $45^{\circ} \mathrm{C}$ for 24 hours, to be conditioned homogeneously, before being submitted to breaking tests. On leaving the oven, these conditioned samples are packaged in aluminum foil, labeled and forwarded to Laboratory of Research in Applied Biology (LARBA) for undergoing the breaking strength measurements. This performed mechanical test is realized in radial compression (patty's diameter direction) by means of Texture Analyzer apparatus TA-Plus model, equipped with a Warner-Bratzler probe and supplied by Lloyd Instruments, a branch of AMETEK Company (USA). It simulates the breaking of patties under the teeth and has been calibrated for fracture strength measurements in the range of 4 to $150 \mathrm{~N}$, at constant elongation of $65 \mathrm{~cm}$, constant speed of $200 \mathrm{~mm} / \mathrm{min}$ and at hole angle of $60^{\circ}$. These force limit values were deduced from preliminary scaling results of such groundnut patties. This proposed mechanical testing method is based on penetrometry technique due to Van Hecke (1991). It allows characterizing the crustiness effort $\left(E_{c}\right)$ which represents an objective measure of felt ease by consumers when 
breaking/fracturing, under tooth, the cell walls structure of extruded products. The crustiness effort $\left(E_{c}\right)$ is calculated by:

$$
\mathrm{E}_{\mathrm{C}}=\mathrm{F}_{\mathrm{GM}} / \mathrm{N}_{0}
$$

Indeed, an extruded product is more crusty that it presents, during its breakage, a high fractures number $\left(\mathrm{N}_{0}\right)$ corresponding to number of peaks of intensity greater than a threshold taken equal to $0.1 \mathrm{~N}$, during solicitation time by a feeble global mean force $\left(\mathrm{F}_{\mathrm{GM}}\right)$. This force is equal to the integral $\left(\mathrm{I}_{\mathrm{F}}\right)$ of area under the force - time curve divided by solicitation time $(\mathrm{t})$. In other words, it can be considered that, a groundnut patty, similar to an extruded product because it also undergoes expansion during frying treatment, is crustier, at constant fractures number $\left(\mathrm{N}_{0}\right)$, when parameter characterizing the crusty effort $\left(E_{C}\right)$ is low. The used Texture Analyzer in this measure allows setting the value of height of probe penetration into material and its descent speed. It thereby makes test time constant. The measured breaking force $\left(\mathrm{E}_{\mathrm{B}}\right)$ is nothing else than the global mean strength $\left(\mathrm{F}_{\mathrm{GM}}\right)$. Therefore, this breaking effort $\left(\mathrm{B}_{\mathrm{s}}\right)$ is made proportional to crustiness effort $\left(\mathrm{E}_{\mathrm{C}}\right)$ at a constant close to $\left(1 / \mathrm{N}_{0}\right)$ as shown by equation:

$$
\mathrm{E}_{\mathrm{C}}=\mathrm{F}_{\mathrm{GM}} / \mathrm{N}_{0}=\left(1 / \mathrm{N}_{0}\right) \cdot \mathrm{B}_{\mathrm{S}} \text {. }
$$

\section{Assessment to sensory quality of patties}

The sensory analysis methods, for evaluating quality of a product, involve the sense organs of human being. The sensory analysis calls for particularly precise and supervised methods. Two main approaches exist according to the purpose of a study (Roudaut et al., 2002; Dacremont, 2003): the analytical approach that includes techniques for specifically measuring the sensory characteristics of a product and the hedonic approach that studies the preference of a food product or the provided pleasure from its tasting by a large group of consumers. We must emphasize here that the tests were focused on students accustomed to consume the patties but, at contrary, uninitiated to these kinds of sensory tests. The done test consists, for every participant, to taste each variant of studied patties presented to him/her, to assign and record an appreciation note on the established survey sheet of paper delivered to each taster.

On this survey sheet page, was written the followed statement: "It's your responsibility to give appreciation on quality aspects "crustiness and taste" for each patties' sample, according to the defined rating scale, at header of Table 2 carrying the followed instructions going from VG (Very Good = 5), JG (Just Good = 4), FG (Fairly Good = 3), PG (Passably Good = 2), PQ (Poor quality $=1$ ) to BQ (Bad quality= 0). A very important subsidiary question finishes this to be filled form: "What is your most beloved patty variant?"

\section{Data statistical analysis}

The collected data from characterization tests, for the nine (09) patties variants, were subjected to statistical analysis for dispersions determination. For every test, the number of samples, for each patty variant, corresponds to the number of times of test replications (n). The standard deviation $(\sigma)$, dispersion's indicator, is then calculated to achieve informations on how variables $\left(\mathrm{X}_{\mathrm{i}}\right)$ are scattered around arithmetic mean-value (m) according to equation.

$\sigma=(1 / n) \cdot \sqrt{\sum_{i} X_{i}^{2}-m^{2}}$

The results of taste tests were analyzed through graphs from processed data using Microsoft Office Excel 2007 software. 


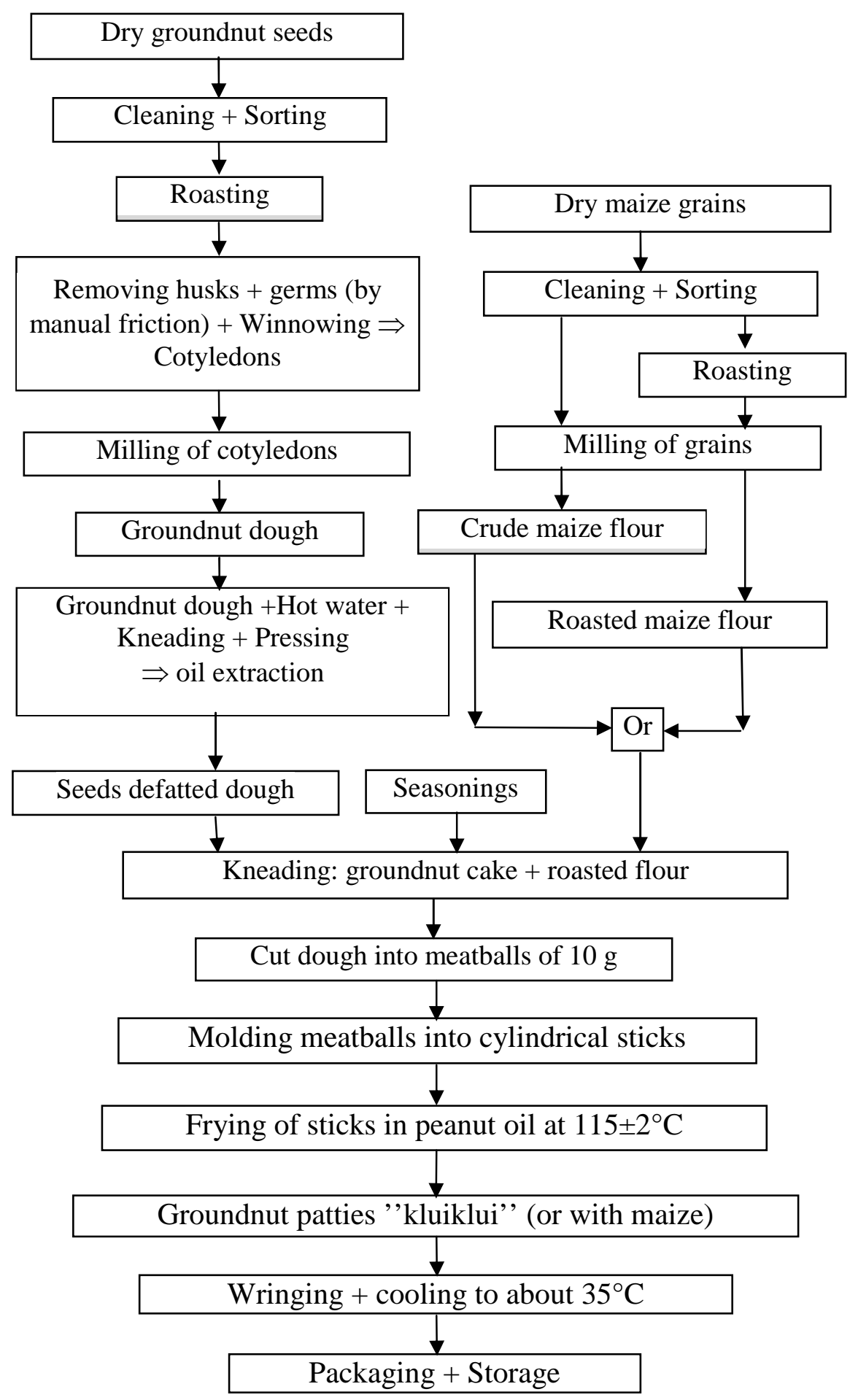

Figure 1: Flow chart of the groundnut patties manufacturing process. 


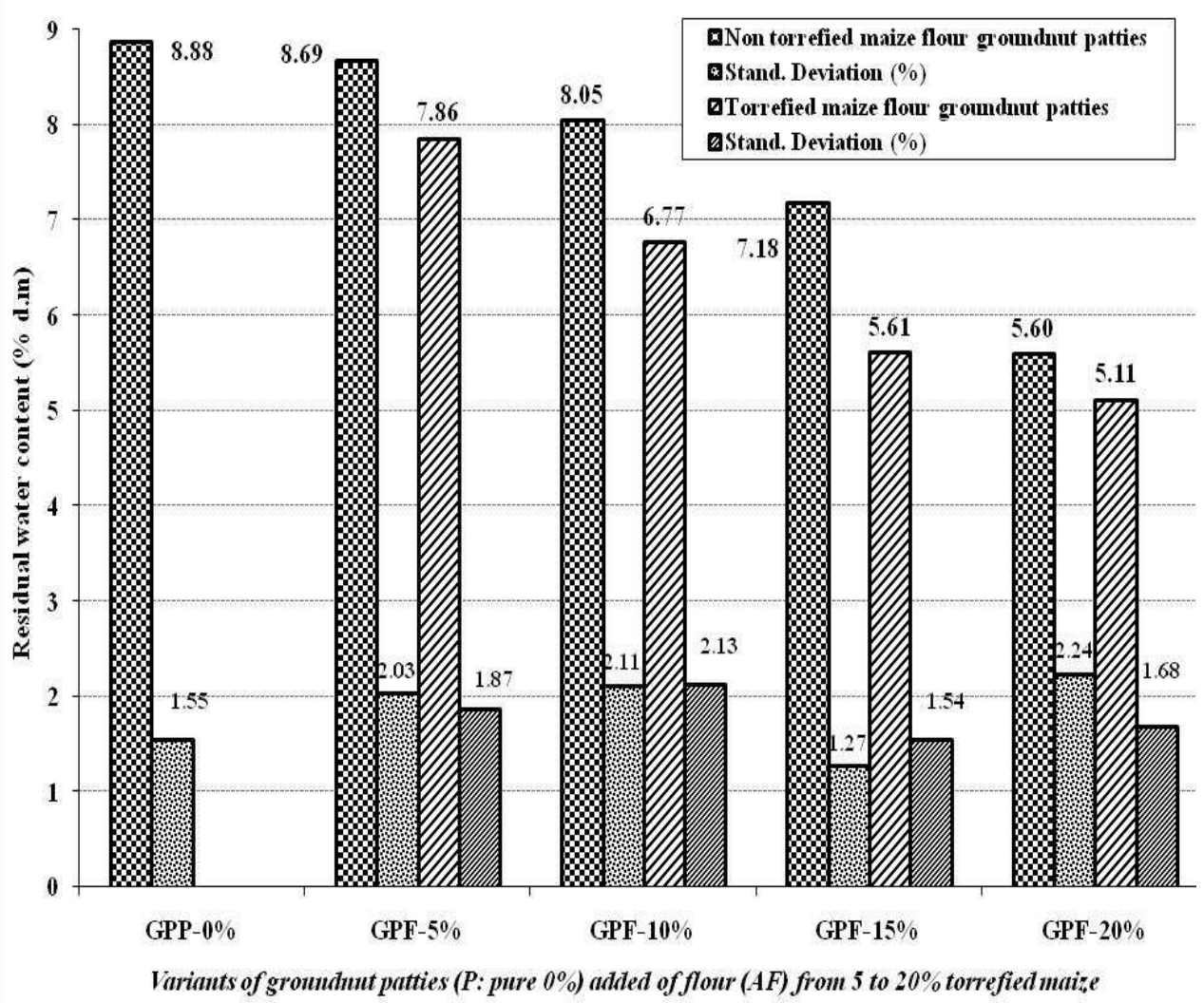

Figure 2: Residual water contents of the studied nine (09) variants groundnut patties.

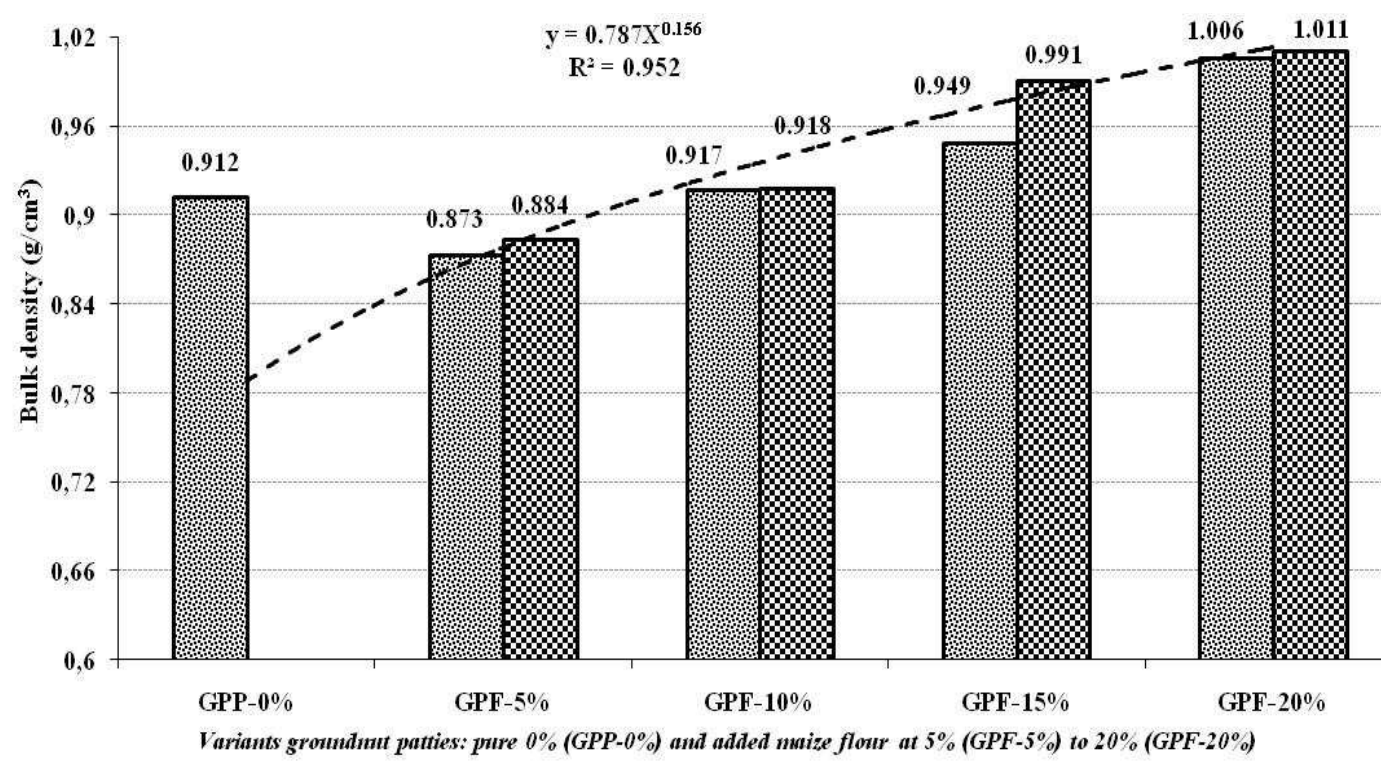

Figure 3: Apparent density of the studied nine (09) variants groundnut patties. 


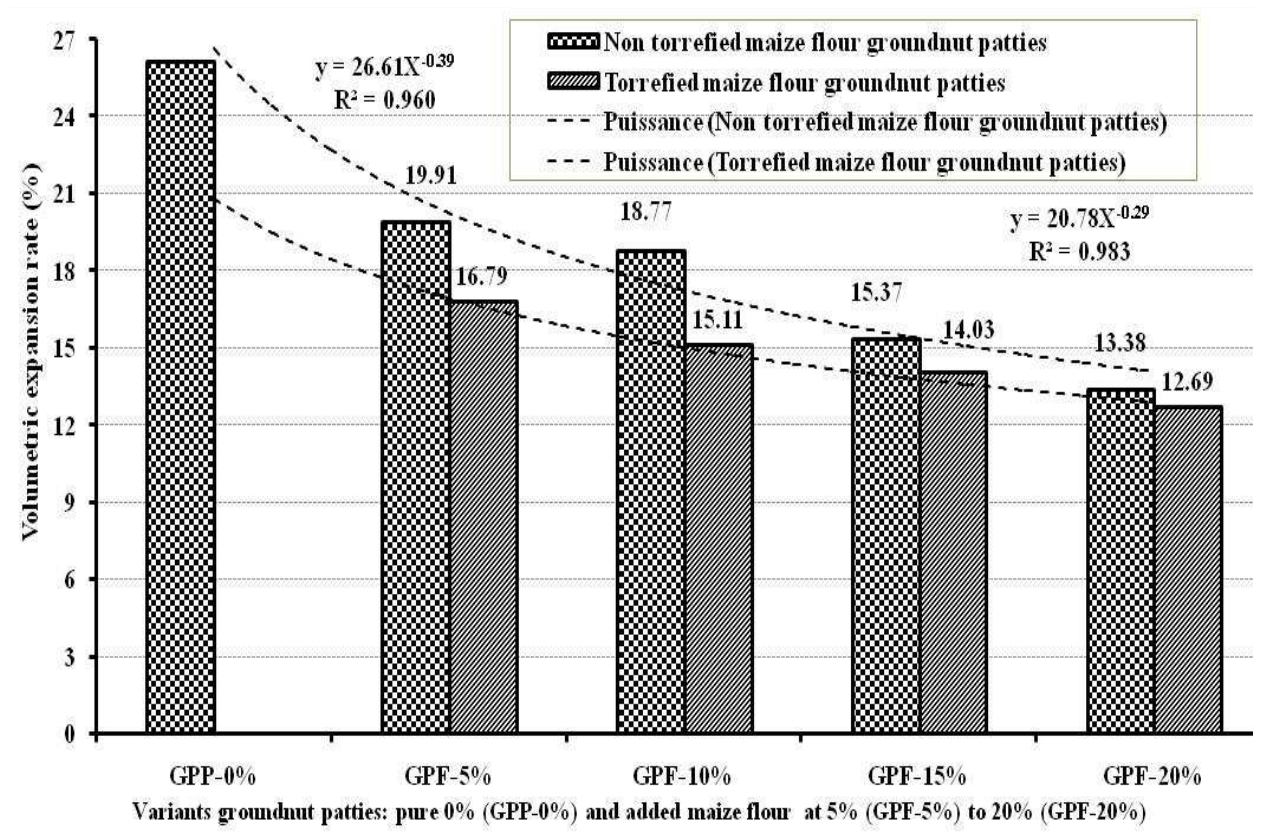

Figure 4: Volume expansion rates of the studied nine variants groundnut patties.

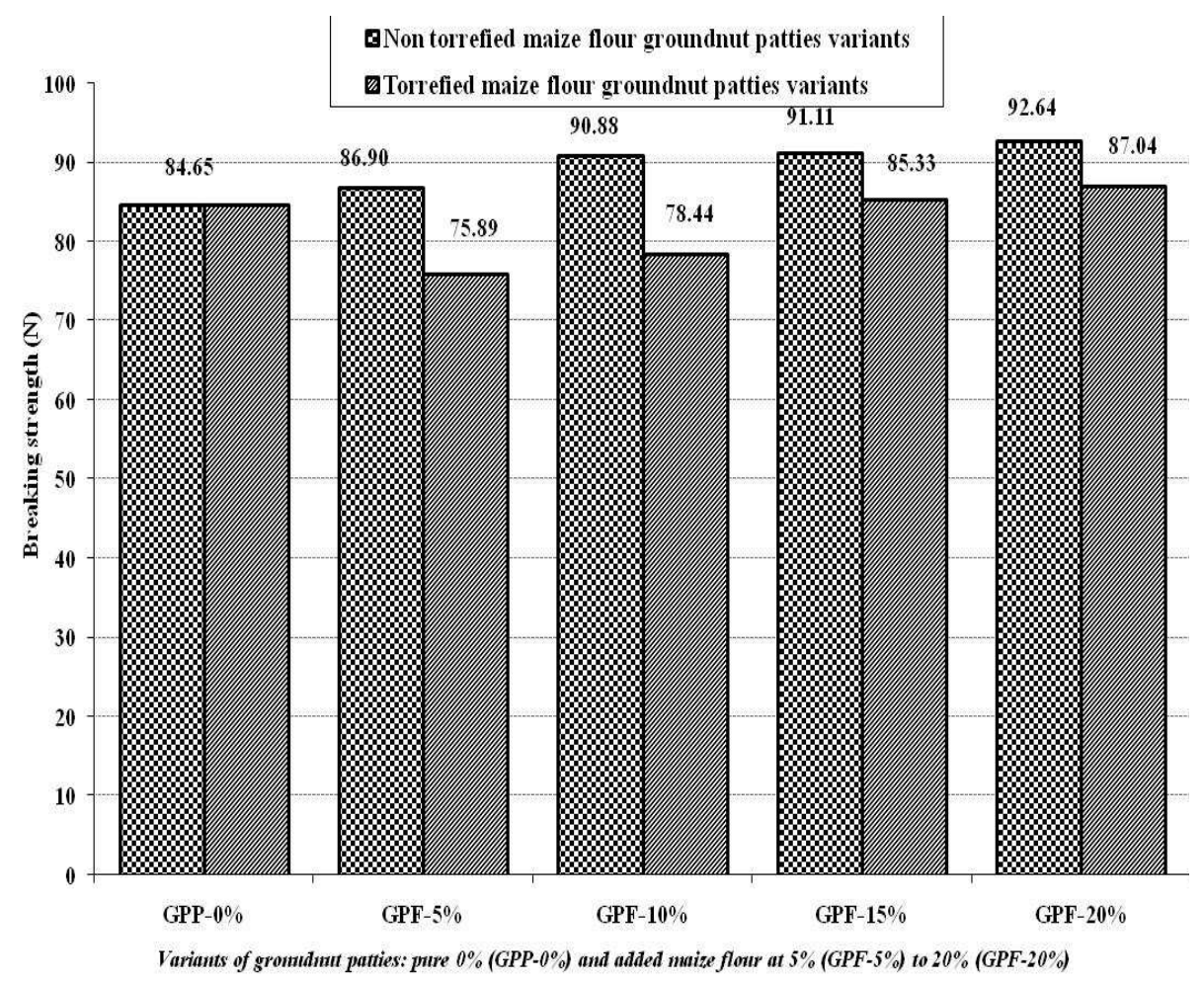

Figure 5: Breaking strength of the nine studied variants groundnut patties. 


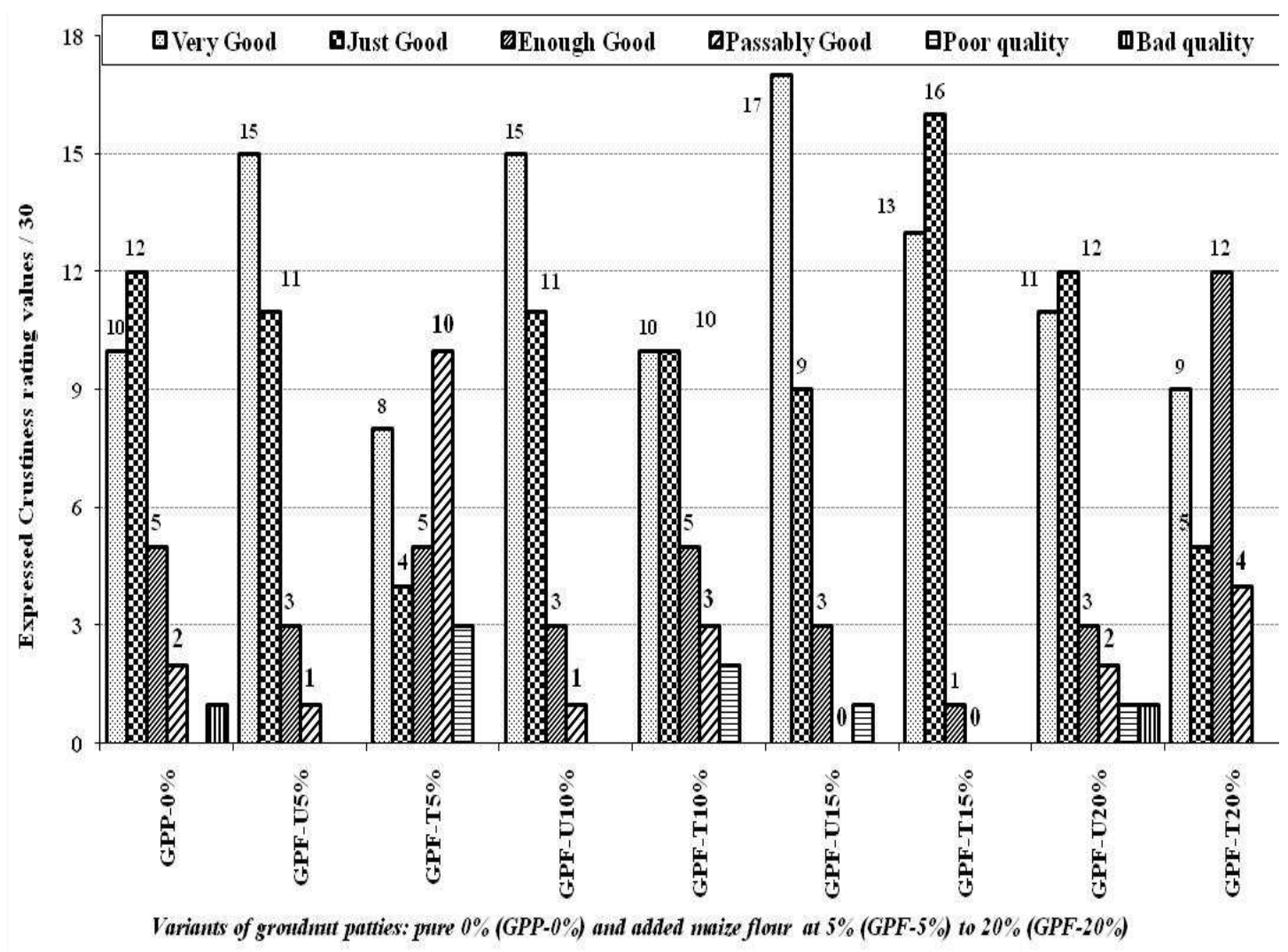

Figure 6: Crustiness study only for variants groundnut patties. 1-without maize flour (GPP-0\%); 2-made of non torrefied maize flour (GPF-U); 3-made of torrefied maize flour (GPF-T) both two latters from 5\% to $20 \%$.

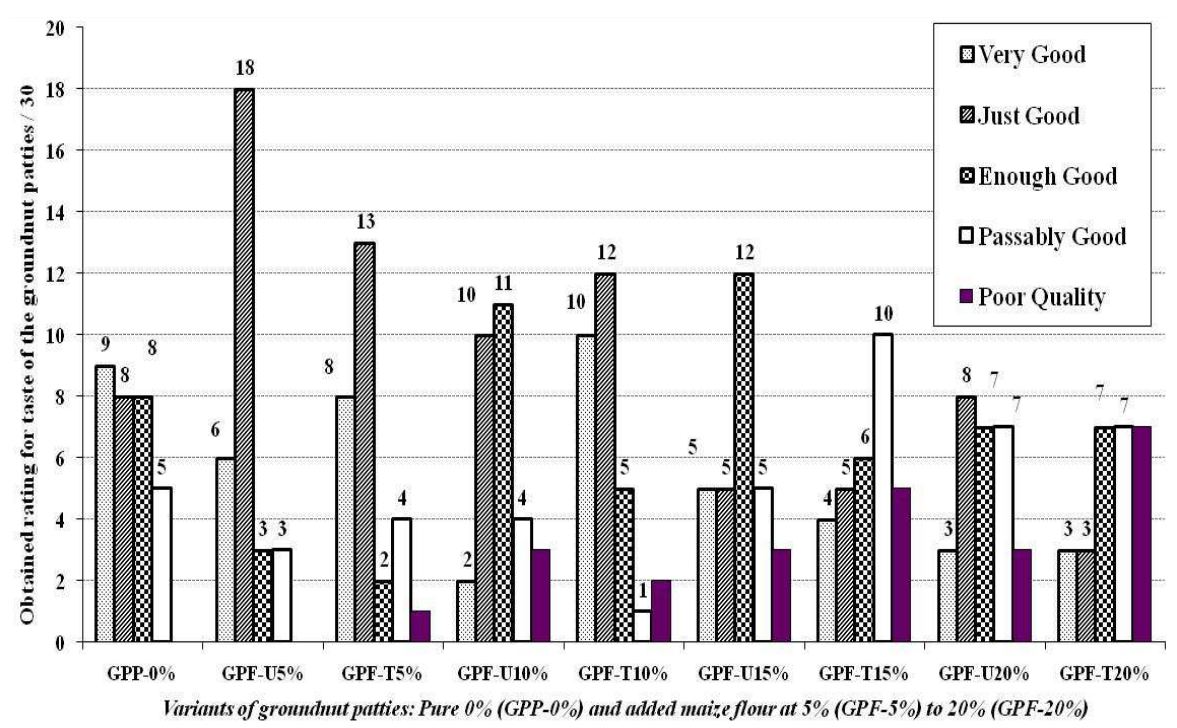

Figure 7: Taste study only for variants groundnut patties. 1-without maize flour (GPP-0\%); 2-made of non torrefied maize flour (GPF-U); 3-made of torrefied maize flour (GPF-T) both two latters from 5\% to $20 \%$. 


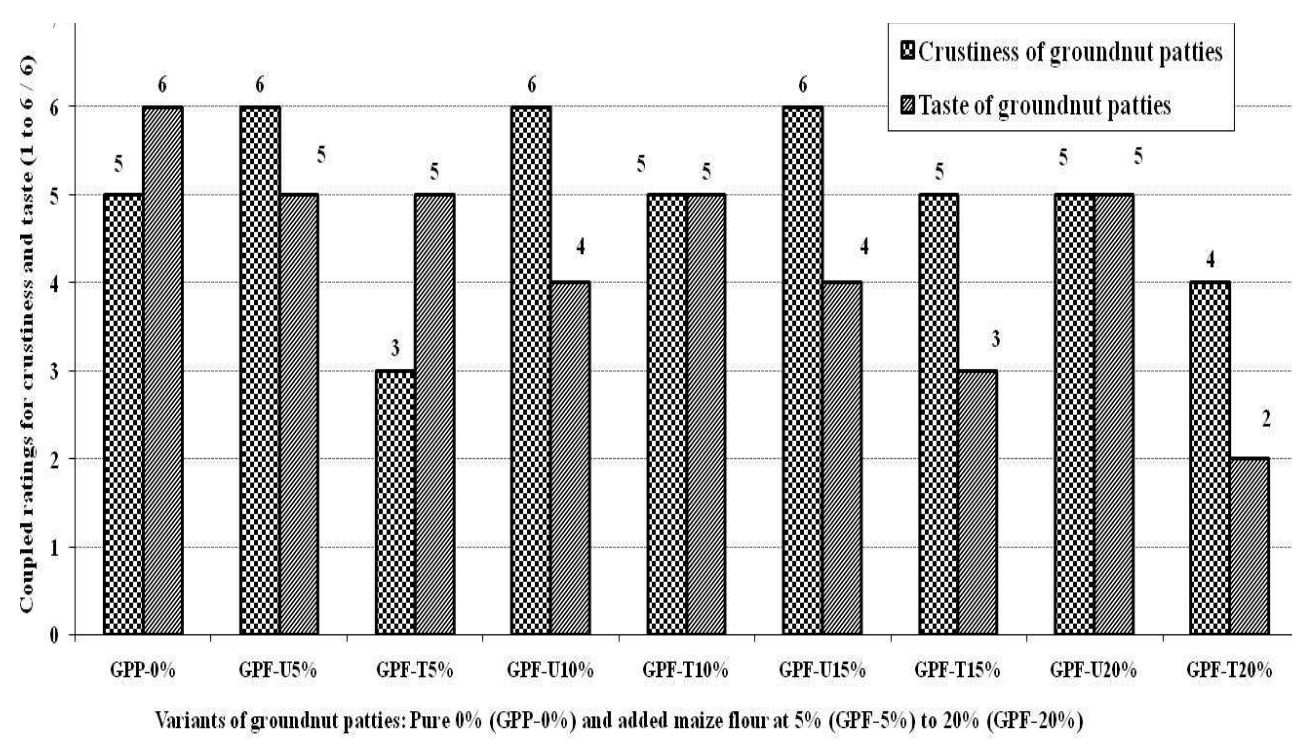

Figure 8: Crustiness and taste combined study for variants groundnut patties. 1-without maize flour (GPP-0\%); 2-made of non torrefied maize flour (GPF-U); 3-made of torrefied maize flour (GPF-T) both two latters from 5\% to $20 \%$.

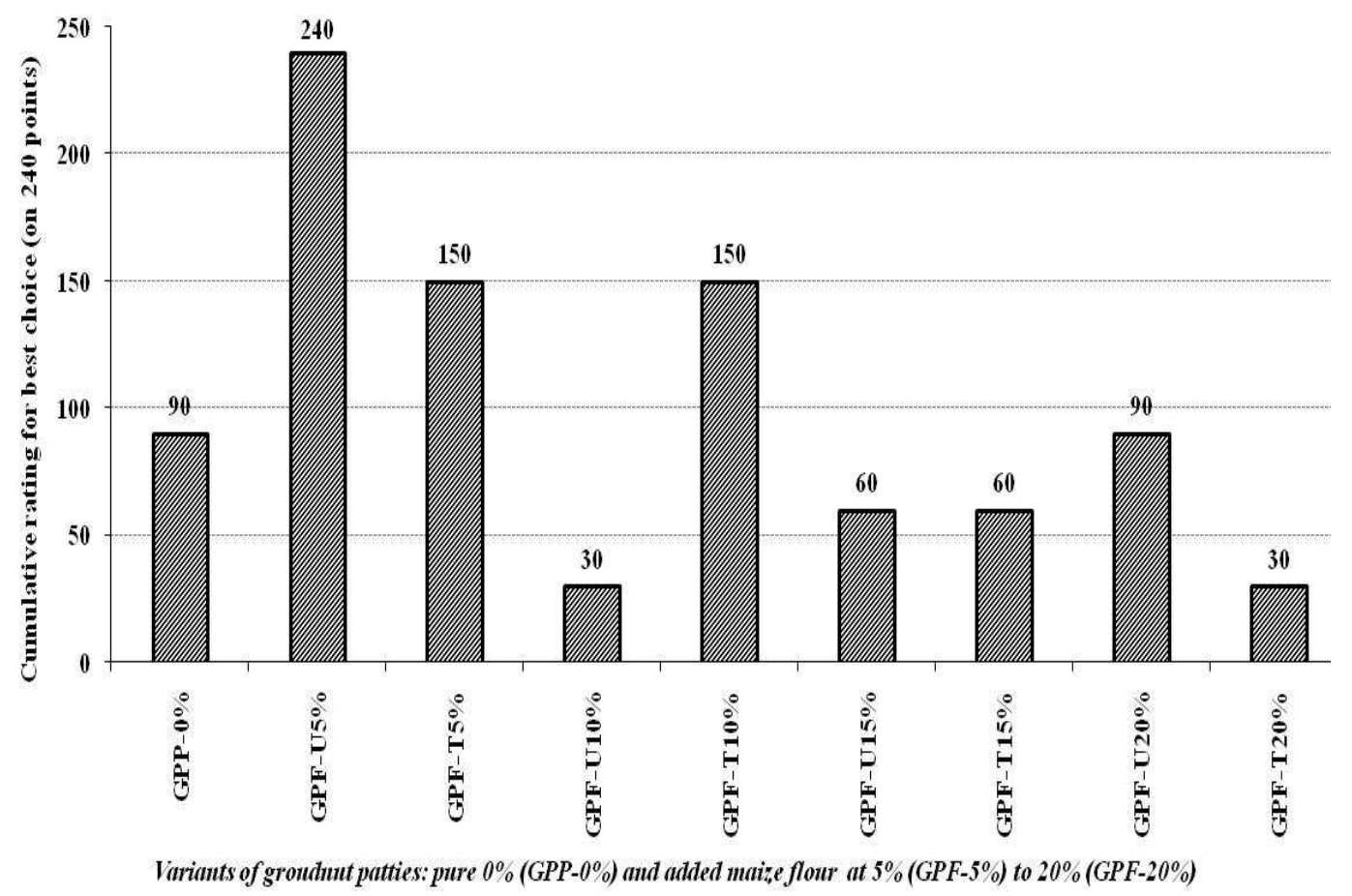

Figure 9: Answers for subsidiary question relating to the most beloved patties variant. 1-without maize flour (GPP-0\%); 2-made of non torrefied maize flour (GPF-U); 3-made of torrefied maize flour (GPF-T) both two latters from $5 \%$ to $20 \%$. 
1995 specifies maximal values of $10 \%$ for unshelled groundnuts and $9 \%$ for nude seeds.

The recorded low residual water content for these patties variants can be explained by the fact that, during roasting process, carbohydrates (starch, proteins and hemicelluloses) of the added maize flour have been denatured, degraded in major part by supplied heat. Accordingly, heat action had to break the potential sites of ion binding (O-) and $(\mathrm{H}+)$ of water molecules which, thus unbalanced, were prevented from attaching much more rigidly compared to same components of corresponding patties, made of unroasted seeds maize flour, displaying higher residual water content. Indeed, molecular chemistry states that, "because hydrogen bonds' existence (weak compared to covalent bonds), a lot of energy is to be provided to vaporize the water, in that these links must first be broken (Le Goff, 1997)". It's then convenient to think that torrefaction has contributed to the hydrogen bonds weakening, in the patties incorporated of flour based torrefied maize grains than non torrefied ones.

The effected exploratory analysis of the displayed trend by the recorded data shows us that the polynomial function that adequately fits the developed behavior by groundnut patties residual water content $(\mathrm{Wr}, \%)$ versus the added maize flour content $\left(\mathrm{T}_{\mathrm{msfc}}\right)$ is of degree 3 , the maize seeds being torrefied or unroasted:

$\mathrm{W}_{\mathrm{r}}(\%, \mathrm{bs})=-0.0219 \cdot \mathrm{T}_{\mathrm{msfc}}^{3}-0.0183 \cdot \mathrm{T}_{\mathrm{msfc}}^{2}-0.0314 \cdot \mathrm{T}_{\mathrm{mscc}}+8.9585$

with regression coefficient value $R^{2}$ of $\mathrm{R}^{2}=0.9991$.

\section{Patties bulk density}

Retained density, for a test, is average density of twelve (12) samples cut for testing. The used value for the bulk density of a patty variant is the average of the obtained values after six (06) testing in this variant. The experimental results, from measurements of the nine (09) patties variants, are disclosed in the graph shown in Figure 3.

By analyzing the collected data, we observed that groundnut patties, produced from classic defatted dough i.e. without any maize flour addition, have deployed an average density of $0.912 \pm 0.044 \mathrm{~g} / \mathrm{cm}^{3}$, thus corroborating results of similar studies on such kinds of patties variants (Guedou, 2010). The addition of maize flour, from crude or roasted grains, at level of 5\% (mix weight), generated a little reduction of patties density: $0.873 \pm 0.042 \mathrm{~g} / \mathrm{cm}^{3}$ and $0.884 \pm 0.034 \mathrm{~g} / \mathrm{cm}^{3}$ corresponding to respective reduction rates of $4.3 \%$ and $3.1 \%$. It's only at $10 \%$ of added flour content that apparent density of these patties variants (respectively $0.917 \pm 0.083$ and $0.918 \pm 0.062 \mathrm{~g} / \mathrm{cm}^{3}$ ) reaches and then slightly exceeds that for no maize flour contain. Additional tests are needed to better refine the registered behavior. However, we can conclude that the patties density increases with increasing maize flour content, the used seeds being roasted or unroasted. Note also that, in regard to our experimental results, the patties produced using $20 \%$ (weight) of maize flour, from roasted or crude seeds, have exhibited apparent densities which values are slightly higher than water's one: respectively $1.006 \pm 0.104 \mathrm{~g} / \mathrm{cm}^{3}$ and $1.011 \pm 0.101 \mathrm{~g} / \mathrm{cm}^{3}$. We can deduce that roasting of the maize seeds has effects of increasing the bulk density of groundnut patties on the one hand, with a more substantial increase than that induced by flour incorporation from crude maize seeds, on the other. In both formulations, the observed increase in the groundnut patties density, following the addition of crude or roasted flours, seems logical. It could be explained by the fact that, a percentage of defatted dough (weakened structure) should be replaced by equivalent proportion of relatively richer maize flour of dry matter (starch and other carbohydrates) partially degraded (regarding roasted maize), able to consolidate this seasoned dough giving the patties. Exploratory analysis of developed trend by the acquired data for produced patties density $\left(\rho_{\mathrm{A}}\right)$ revealed that the polynomial function that adequately fits the developed behavior by groundnut patties, versus the added maize flour content $\left(\mathrm{T}_{\mathrm{msfc}}\right)$ is of degree 3 , the maize seeds being torrefied or 
unroasted. For the blended patties variants using the torrefied seeds flour content $\left(\mathrm{T}_{\mathrm{msfc}}\right)$, it's given, at four decimal places, by:

$\rho_{A}\left(\mathrm{~g} / \mathrm{cm}^{3}\right)=-0.0001 \cdot\left[T_{\text {masc }}\right]^{3}+0.0050 \cdot\left[T_{\text {mssc }}\right]^{2}-0.0437 \cdot\left[T_{\text {ms }}\right]+0.1097$ (10)

and as regards the variants patties made of unroasted maize seeds flour content $\left(\mathrm{U}_{\mathrm{msfc}}\right)$, by:

$\rho_{\mathrm{A}}\left(\mathrm{g} / \mathrm{cm}^{3}\right)=0.0001 \cdot\left[\mathrm{U}_{\mathrm{mscc}}\right]^{3}-0.0020\left[\mathrm{U}_{\mathrm{mscc}}\right]^{2}+0.0297 \cdot\left[\mathrm{U}_{\mathrm{mscc}}\right]-0.1065$ (10')

with regression coefficient values $R^{2}$ respectively equal to $R^{2}=1.0000$.

\section{Patties volume expansion rate}

The adopted value, for volume expansion rate from a test, is mean-value of the determined rates over twelve (12) samples. Then, the adopted value, for a patties variant, is average of the achieved expansion rates relative to six (06) replications corresponding to seventy two (72) tested samples. The obtained results for volume expansion rates of these nine (09) studied patties variants are shown in the Figure 4.

These results support the conclusion that, at identical flour percentages, the patties variants produced by incorporating the roasted seeds maize flour to the defatted groundnut dough, have developed a relatively low volume expansion rate compared to those fabricated using the crude maize flour. The torrefaction of maize seeds, added in flour form, has had the effects of reducing the groundnut patties volumetric expansion rate. In addition, our results have also revealed that, when percentage of added flour, from the roasted maize, increases, groundnut patties volumetric expansion rate decreases. Similar trend is obtained for patties variants made in adding obtained flour from non torrefied maize seeds to groundnut dough, at identical proportions. Exploratory analysis of developed trend by the acquired data on the produced patties volume expansion rate $\left(\varepsilon_{\mathrm{V}}\right.$, $\%$ ) revealed that the mathematical model that adequately fits the obtained behavior versus the added maize flour content $\left(\mathrm{T}_{\mathrm{msfc}}\right)$ is a logarithmic function, the maize seeds being torrefied or unroasted.
For groundnut patties variant blended of torrefied maize seeds flour $\left(\mathrm{T}_{\mathrm{msfc}}\right)$, equation is: $\varepsilon_{\mathrm{v}}(\%)=-4.36 \cdot \mathrm{Ln}\left[\mathrm{T}_{\mathrm{msfc}}\right]+19.87 \mathrm{R}^{2}=0.992$ (11)

For groundnut patties made of flour from unroasted maize seeds $\left(\mathrm{U}_{\mathrm{msfc}}\right)$, model equation is:

$\varepsilon_{\mathrm{v}}(\%)=-7.63 \cdot \mathrm{Ln}\left[\mathrm{U}_{\mathrm{msfc}}\right]+26.02 \mathrm{R}^{2}=0.980 \quad\left(11^{\prime}\right)$

These two equations clearly indicate that, at identical percentages of added maize flour, higher values of volume expansion rates are obtained for manufactured groundnut patties' variants using the unroasted maize seeds flour compared with those blended of roasted seeds.

\section{Patties mechanical characteristics}

The assessed results for textural properties analysis, through breaking force measurements (in radial compression using the Texture Analyzer apparatus), for the nine (09) studied variants groundnut patties, are displayed in Figure 5. As previously described, case of volume expansion rate, the adopted value for breaking strength for patties variant, is the mean-value from six times replicated tests, twelve samples basis, equivalent to seventy-two (72) samples.

Those disclosed experimental results show that the produced patties variants, using torrefied grains maize flour incorporation, fracture more easily $(75.89$ to $87.04 \mathrm{~N}$ ) than variants made of unroasted seeds maize flour $(84.65$ to $92.64 \mathrm{~N})$ which are therefore more resistant. It can be concluded that, application of torrefaction to maize seeds had the effects of weakening the material solid structure, making thus the treated patties relatively softer and easier to break than those from flour of the unroasted maize seeds. These results are fairly consistent in focusing on the fact that the added crude maize flour brings its components to further strengthen the solid structure of groundnut defatted dough. The latter is also vulnerable because it derives from roasted nuts in normal processing. The heat treatment has degraded structural links of fibrous constituents made of carbohydrates dedicated to natural reinforcement of structure such as starch, proteins and hemicelluloses 
(Claude and Ubbin, 2006). All these components were weakened in the case of flour from roasted maize grains. It's noted however that, the more the added percentage of torrefied maize flour to dough formulation increases, the higher the breaking strength of corresponding patties, even if the growth rate seems relatively low, reaching about $12.81 \%$ for a maize flour added rate of $20 \%$ (weightin-mix). Exploratory analysis of the developed trend by the acquired data on patties breaking strength $\left(\mathrm{B}_{\mathrm{S}}\right.$ seeing $\mathrm{E}_{\mathrm{c}}$ at constant $1 / \mathrm{N}_{0}$ rounded) revealed that, the mathematical model that adequately fits the obtained behavior versus the added maize flour content $\left(\mathrm{T}_{\mathrm{msfc}}\right)$ is a polynomial function, the maize seeds being torrefied or unroasted. Choosing function relatively to torrefied maize flour content $\left(\mathrm{T}_{\mathrm{msfc}}\right)$, equation of this function is given by:

$\mathrm{B}_{\mathrm{s}}=-0.21 \cdot\left(\mathrm{T}_{\mathrm{msfc}}^{2}\right)+5.1 \cdot\left(\mathrm{T}_{\mathrm{mscc}}\right)+75.89$

$\mathrm{R}^{2}=0.95$ (12)

These experimental results have also allowed noting that, addition of the crude maize seeds flour contributes to the breaking strength increase: about $9.44 \%$ at flour content of $20 \%$, a relatively feeble value compared to that from torrefied maize grains flour (12.81\%).

\section{Patties sensory quality analysis}

The obtained results, from the recorded and treated data, during the done tests, are shown in diagrams of Figures 6, 7 and 8. The specificity of sensory tests, in this investigation, lies in the fact that, all the tasters are students from Abomey-Calavi Campus. They are, neither trained, nor gathered in one place for realized tests, but were volunteered, met here and there, on the Campus and freely agreed to participate in these proposed tests to them.

\section{Study of patties crustiness only}

On Figure 6 are deployed the obtained results from sensory appreciation of a staff of thirty (30) students who accepted filling column of the established survey sheets, relative only to crustiness of the tasted groundnut patties.
It can globally be noted that, virtually all the nine (09) variants of patties are acceptable for the tasters. This is due to the almost nullity collected in the entitled boxes as Poor Ratings (except GPF-T5\% where the scores have reached $3 / 30=1 / 10$ ) and also for Zero or "Bad quality" (1/30) and mainly because of the width of the recorded high scores between "Fairly Good" (10/30 sole GPF-T5\%) and "Very Good" assessments. On the basis of obtained scores for the assessed parameters of quality point of view, the best variant of these produced nine groundnut patties is the one incorporated at $15 \%$ maize flour mass-in-mix, using unroasted grains (GPF-U15\%). It's respectively followed by variant patties made of unroasted maize flour at respective rates of $5 \%$ (GPF-U5\%) and $10 \%$ (GPF-U10\%). These results show that, the best groundnut patties, for quality aspect relating to crustiness, are confectioned variants using unroasted maize seeds flour at incorporation rates, respectively of $15 \%$ (GPF-U15\%), 10\% (GPF-U10\%) and 5\% (GPF-U5\%) in this classified order. Only the manufactured patties variant, using $15 \%$ flour (weight-in-mix) of torrefied maize seeds, has emerged by collecting respondents' score of 16/30 for "Very Good" notation.

\section{Study of patties taste only}

On Figure 7 are displayed the obtained results, from the same staff/panel of thirty (30) students, relating only to the taste aspect of the produced nine variants groundnut patties.

It must be noticed that, these achieved results allowed us drawing an important and interesting conclusion relating to the fact that our respondents showed ability in making a very good distinction between patties "crustiness" and "taste", two different quality aspects. Remember that on the one hand, they are neither trained, nor gathered for running the realized sensory tests, on the other. Such a feeling capability seems very important for assessing the food quality. Therefore, taking into account the best rating concerning "Very Good", the confectioned patties variant using groundnut dough supplemented at $10 \%$ flour 
from torrefied maize grains (GPF-T10\%), provides the best taste: score of 10/30 "Very Good". It's followed, at barely a point difference, by the pure defatted dough variant patties (GPP-0\%). When the quality assessment goes down to rating "Good", tasting results show, at this moment, that the groundnut patties variant blended at $5 \%$ of unroasted seeds maize flour (GPF-U5\%) collects the best "taste" score (18/30) followed by patties variants containing $5 \%$ and $10 \%$ torrefied maize seeds flour at $13 / 30$ score for GPF-T5\% and at 12/30 score for GPF-T10\%. All the others studied groundnut patties variants got respective scores lower than $10 / 30$ for "taste".

From this realized "taste" tests, it follows that, if desire is to manufacture groundnut patties variants insuring a good taste (Enough-Good Rating), maize flour proportion to integrate to seasoned dough formulation, either from torrefied or unroasted seeds, shall be lower or equal to $15 \%$ (weight-in-mix).

Combined study of patties crustiness with taste

If the will is to combine both two aspects of these studied organoleptic quality i.e. a "best crustiness" with a "best taste", we can then conclude, from these investigated nine (09) groundnut patties variants (Figure 8) that, the confectioned patties variant without any addition of maize flour (GPP-0\%) emerges as the best of all. It combines, "Very Good" notation and a "best taste" to the "most favorable crustiness". The variant of patties, which allies, in a very good way, at contrary, the "best crustiness" to a "very favorable taste", is the variant made of $5 \%$ unroasted seeds maize flour (GPF-U5\%). Also, note that, all the patties variants, produced using flour from non-torrefied maize grains, are judged most crusty by respondents compared to those confectioned from the torrefied grains.

Such results are fully consistent with those ensuing from the volume expansion rate measurements. However, they seem conducting, a priori, to fault, the assessed results from the breaking strength study. But in reality, it is not the case, because, by bringing results of apparent density analysis closer to the volume expansion rate ones, for different patties variants, we can notice and then better explain, the expected normally trend for crustiness, but not unfortunately reached. Indeed, densities of the blended patties of torrefied maize flour showed a higher increase than did those made of unroasted maize flour at explored range percentages. At the same time, although the volume expansion rate of the blended groundnut patties using torrefied maize seeds flour increases with their flour content, it remains lower compared to those recorded for patties variants made of unroasted maize flour, at identical incorporated percentages. The collected results show that the latters are less expanded and, so, possess more packed structure than the former. Subsequently, the roasted maize flour incorporated groundnut patties are then found less crusty. This can be explained by the fact that their low volume expansion rates handset to their denser structure compared with those of the confectioned patties using unroasted maize seeds flour.

\section{Consumers most loved variant patties}

On Figure 9 are disclosed the obtained results, from the same staff of thirty (30) students and same test sheet, relating to the asked subsidiary question on the "most loved" groundnut patties variant: "as responder's personal appreciation". Analysis of these results presented on Figure 9 clearly shows that the overall done assessment by tasters is oriented towards the blended variant of manufactured groundnut patties using the unroasted maize flour at 5\% weight-in-mix (GPF-U5\%). Such results from consumers' personal appreciation are satisfactory and partially confirm the obtained trend in the done preliminary works relative to this subject (Sanya et al., 2013).

Variants of groundnut patties, without any maize flour addition ( $0 \%)$, on the one hand and those containing $5 \%$ of crude/unroasted seeds maize flour, on the other, stood out as being significantly more 
crusty. In the considered general assessment in present work, we rather ally "crustiness" and "taste", important two quality parameters for groundnut patties. Moreover, it can be observed that, the variants of groundnut patties added of $5 \%$ flour of non-torrefied maize seeds, are followed, relatively far away at equal ratings, by both the variants of peanut patties blended of flour from torrefied maize grains at respectively $5 \%$ and $10 \%$ (weight-inmix). This confirms, once again, the preceding work results concerning the crude maize flour (Sanya et al., 2013) stipulating that, "if one wants to manufacture the groundnut patties variant, blended with maize flour, having quality that best meets consumers' personal appreciation", the maize flour percent to choose must be comprised between 5 and $15 \%$.

\section{Conclusion}

The reported experimental research was mainly dedicated to study torrefaction influences of maize grains on some physicomechanical and organoleptic characteristics of the manufactured groundnut patties' variants by incorporating $5 \%, 10 \%, 15 \%$ and $20 \%$ maize flour (weight-in-mix). From analysis of the obtained results, we concluded that torrefaction induced significant reduction for residual water content of maize flour blended groundnut patties from torrefied maize grains. Such this noticed effect was interesting and favorable to a sustainable conservation of corresponding patties variant compared to those confectioned using the non-torrefied maize flour. The torrefaction of maize seeds significantly induced reducing effects, not only on residual water content, but also on volume expansion rate, breaking strength and crustiness of the studied patties whilst conferring to them a bulk density increase. The outcomes of these effected taste tests also confirmed that the manufactured groundnut patties variants, using the non-torrefied maize flour, were crustiest than did the ones torrefied, at equal percentages maize incorporation. If the patties variant made of pure defatted groundnut dough (GPP-0\%) gained the highest score, in terms of the taste appreciation, the blended variant at $5 \%$ crude maize flour rather removed the score of "best crustiness" coupled with "good taste", confirming, by this way, physico-mechanical results stating that: "the more low were values of breaking strength and apparent density of the confectioned groundnut patties variants maize flour incorporated, the higher the taken values by their volume expansion rate". Further investigations will specifically be devoted to the deep knowledge of nutritional values of emerging variants of maize flour blended peanut patties from the lot, primarily those made respectively of $5-10 \%$ unroasted and $5-10 \%$ roasted flours.

\section{ACKNOWLEDGEMENTS}

We address our deep gratitude, respectively to $\mathbf{M}^{\text {me }}$ Marie Azédjo, patties producer, for material and moral contributions mainly through its production unit, as well as to Mr. Serge Ahounou; Doctor Tougan P. Ulbad and Professor Issaka A.K. Youssao, all from LARBA (EPAC), for their supplied technical assistance during this work.

\section{REFERENCES}

Adjadja OAP. 2004. Analyse économique du système de commercialisation des beignets de pâte déshuilée d'arachide 'kluiklui', dans la commune de DassaZounmè, Thèse présentée en vue d'obtention du diplôme d'Ingénieur Agronome, ESAC/FSA, Bénin. 86 p.

Asiédu JJ. 1991. La Transformation des Produits Agricoles en Zone Tropicale: Approche Technologique. Editions Kharthala/ CTA; 332 p.

Bourne MC. 2002. Food Texture and Viscosity: Concept and Measurement $\left(2^{\text {nd }}\right.$ edn). Academic Press: New York; 427.

Brink M, Belay G. 2006. Céréales et Légumes Secs (vol 1). Ressources Végétales de l'Afrique Tropicale, Editions GJH Grubben. Nature, PROTA : Leiden; 327.

Brown WE, Braxton D. 2000. Dynamics of Food Breakdown during Eating in 
Relation to Perceptions of Texture and Preference: a Study on Biscuits. Food Pref. Qual., 11: 259-267.

Bruneton J. 2009. Pharmacognosie Phytochimie, Plantes Médicinales $\left(4^{\mathrm{e}}\right.$ édn, revue et augmentée). Tec \& Doc Éditions Médicales Internationales : Paris ; 1288.

Claude J, Ubbin J. 2006. Thermal Degradation of Carbohydrate Polymers in Amorphous States: A Physical Study including Colorimetry. Food Chem., 96: 402-410.

Cimmyt. 1991. Réalités et tendances. Le maïs dans le monde: le potentiel maïsicole de l'Afrique Subsaharienne, CIMMYT 1989/90, Mexico.

Dacrémont C. 2003. Croustillant: aspects méthodologiques de la mesure sensorielle d'une caractéristique de texture complexe. Anthropol. Food, AOF, 01 Septembre 2003 ; 13p.

Diop A, Hounhouigan DJ, Kossou KD. 1997. Conservation et Transformation des Grains. Volume 1. In Manuel de Référence aux Techniciens Spécialisés. Technologie Post-Récolte et Commercialisation des Produits Vivriers. A. Diop ADA Experts Conseils Edition : Québec, Canada ; 1-97.

Fallico B, Arena E, Zappalà M. 2003. Roasting of Hazelnuts. Role of Oil in Colour Development and Hydroxymethylfurfural Formations. Food Chem., 81: 569-573.

FAO. 1993. Le Maïs dans la Nutrition Humaine.. Séries Alimentation et Nutrition, Collection FAO, Italie, 25: 174.

FAO. 2006. Perspectives Agricoles de l'OCDE et de la FAO: Agriculture et Alimentation. OECD Publishing ; 224 p.

FAO. 2010. Système d'Information des Ressources en Alimentation Animale. Food and Agriculture Organization. FAOSTAT.

Fillion L, Kilcast D. 2002. Consumer perception of crispness and crunchiness in fruits and vegetables. Food Qual. Prefer., 13: 23-29.

Guédou GN. 2010. Caractérisation physicomécanique des galettes béninoises à base de farines d'arachides et de maïs: Mise au point et validation d'un protocole expérimental. Mémoire de DEA/SPI, Université d'Abomey-Calavi, Bénin, 87 p.

Hayford EA. 1998. Characterization of the dominant micro biota of Ghanaian maize fermentation (Kenkey). PhD Thesis, Royal Veterinary and Agric. Univ., Denmark, 183 p.

Hounhouigan DJ. 1994. Fermentation of maize (Zea mays L.) meal for mawè production in Benin: Physical, Chemical and Microbiological Aspects. PhD Thesis, Agricultural University of Wageningen, The Netherlands, $99 \mathrm{p}$.

Le Goff L. 1997. "Nourrir la Vie". Encyclopédie de l'Alimentation Biologique et de l'Equilibre Nutritionnel. 736 p. Réf. 2660.

Linné CV. 1753. Species plantarum (Les espèces de plantes). Tome 1. Amaryllidaceae. Galanhus. Hort. ups. 73. Roy. Ljubljana, 134 p.

Matiacevich SB, Buera PM. 2006. A critical evaluation of fluorescence as a potential marker for the Maillard reaction. Food Chem. 95: 423-430.

Maiti RK, Wesche-Ebeling P. 2002. The Peanut (Arachis hypogaea) Crop. Sciences Publishers Editions: Cornell. University: Cornell ; 376.

Mayeux AH. 2001. Dossier technique sur les normes de production de stockage et la distribution de semence d'arachide en milieu paysannal, CIRAD. $15 \mathrm{p}$.

Nago MC. 1989. Technologies traditionnelles et alimentation au Bénin: aspects techniques, biochimiques et nutritionnels. Identification et caractérisation des principales filières et technologies du secteur traditionnel de transformations alimentaires. Thèse de doctorat. Faculté des Sciences 
Agronomiques / UNB. Abomey-Calavi, Benin, $222 \mathrm{p}$.

Nago MC, Hounhouigan DJ. 1990. La technologie traditionnelle de transformation du maïs en pâte fermentée au Bénin. Faculté des Sciences Agronomiques (IRAT - CEE). $30 \mathrm{p}$.

Paulet JV. 2010. Amélioration des Procédés Traditionnels de Transformation de certains Oléagineux et du Manioc. Division Nutrition \& Alimentation, Editions FAOSTAT; 53 p.

Redgwell JR, Trovato V, Curti D, Fischer M. 2002. Effect of roasting on degradation and structural features of polysaccharides in Arabica coffee beans. Carbohydrates Res., 337: 421-431.

Roudaut G, Dacremont C, Pamies BV, Colas B, Le Meste M. 2002. Crispness: a critical review on sensory and material science approaches. Tren. Food Sci. Technol., 13: 217-227.

Sanya EA, Ahouannou C, Chaffa G, Soumanou MM. 2013. Effects of added Maize Flour on Physicomechanical
Properties of Benin Patties made of Defatted dough of Groundnut Seeds "Arachis hypogeae". Int. J. Current Research, 5(02): 212-218.

Sauvageot F, Depledt F. 2002. Evaluation sensorielle des produits alimentaires. Techniques de l'Ingénieur. Réf. F4000. Agroalimentaire.

Sidibé M. 2005. Migrants de l'arachide: la conquête de la forêt classée de Pata, Casamance, Sénégal. Editions Institut de la Recherche pour le Développement; $301 \mathrm{p}$.

Souci SW, Fachmann W, Kraut H. 2008. La Composition des Aliments: Tableaux des Valeurs Nutritives, Grahame RH, Simmonds A, Carey E (eds). Medpharm Scientific Class Publishing Ltd.

Xiaoyan Z, Jun C, Fangling D. 2012. Potential use of peanut by-products in food processing: a review. J. Food Sci. Technol., 49(5): 521-529. 